\title{
Asymmetric Synthesis of a DPP-4 Inhibitor
}
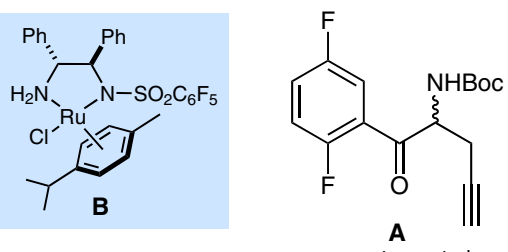

mp not reported

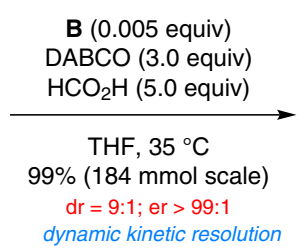<smiles>C#CC[C@H](NC(C)(C)C)[C@@H](O)c1cc(F)ccc1F</smiles><smiles>C#CC[C@H](NC(=O)OCc1ccccc1)[C@H](O)c1cc(F)ccc1F</smiles>

$\mathrm{CpRu}\left(\mathrm{PPh}_{3}\right)_{2} \mathrm{Cl}(0.022$ equiv) $\mathrm{PPh}_{3}$ ( 0.066 equiv) $\mathrm{N}$-hydroxysuccinimide ( 0.5 equiv) $\mathrm{NaHCO}_{3}(0.5$ equiv) $\mathrm{Bu}_{4} \mathrm{NPF}_{6}$ ( 0.13 equiv) DMF, $85^{\circ} \mathrm{C}, 26 \mathrm{~h}$.

(139 $\mathrm{mmol}$ scale)
Gategory

Synthesis of Natural

Products and

Potential Drugs

\section{Key words}

DPP-4 inhibitors

asymmetric transfer hydrogenation

dynamic kinetic resolution

cycloisomerization

reductive amination

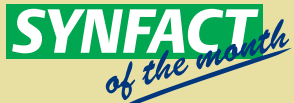

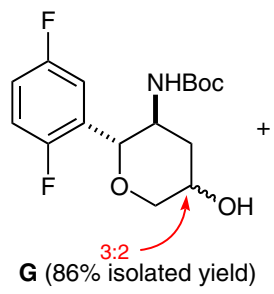<smiles>Fc1ccc(F)cc1</smiles><smiles>CC1(O)CO[C@H](N)C(=O)O1</smiles>
97:3 H (rejected to $0.5 \%$ )
$\mathrm{BH}_{3} \cdot \mathrm{SMe}_{2}$ (1.5 equiv) PhMe-MTBE, $-7{ }^{\circ} \mathrm{C}, 2.5 \mathrm{~h}$; then $\mathrm{NaBO}_{3}$ (3.0 equiv) (79 mmol scale)

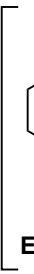<smiles>CC(C)(C)OC(=O)NC1CC=CO[C@H]1c1cc(F)ccc1F</smiles>

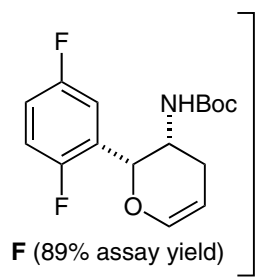

$$
\begin{aligned}
& \mathrm{NaBrO}_{3} \text { (0.5 equiv) } \\
& \mathrm{RuCl}_{3}(0.002 \text { equiv) } \\
& \mathrm{MeCN}-\mathrm{HOAc}-\mathrm{H}_{2} \mathrm{O}(6: 1: 1), 0^{\circ} \mathrm{C} \\
& 85 \%(121 \mathrm{mmol} \text { scale })
\end{aligned}
$$<smiles>CC(C)(C)OC(=O)NC1CC(=O)CO[C@H]1c1cc(F)ccc1F</smiles>

mp not reported
$\mathbf{J}$ (1.1 equiv)

$\mathrm{NaBH}(\mathrm{OAc})_{3}$ (1.2 equiv)

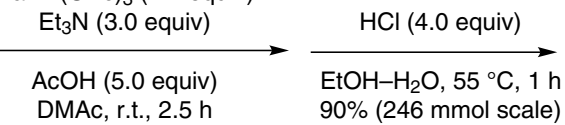
$88 \%(290 \mathrm{mmol}$ scale $)$

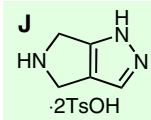

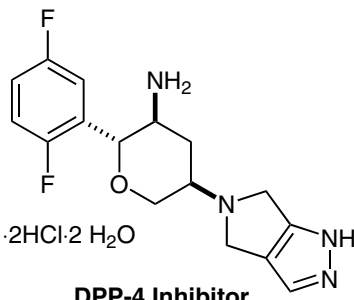

Significance: The target tetrahydropyran DPP-4 inhibitor was of interest for the treatment of type 2 diabetes. The synthesis depicted features three tandem ruthenium-catalyzed reactions: (1) an asymmetric transfer hydrogenation of ketone $\mathbf{A}$ with dynamic kinetic resolution (2) a cycloisomerization to form a dihydropyran ring and (3) an oxidation. The overall yield of the synthesis is $25 \%$.
Comment: Extensive optimization of the asymmetric transfer hydrogenation established that significant contributors to the yield, dr and er included the use of the pentafluoro-substituted DAIPEN catalyst B, DABCO as the base and THF as the solvent. The reductive amination of ketone I with $\mathrm{NaBH}(\mathrm{OAc})_{3}$ dramatically improved $(\mathrm{dr}=19: 1)$ using DMAc as solvent when the bis(tosylate) salt $\mathbf{J}$ was neutralized with $\mathrm{Et}_{3} \mathrm{~N}$ followed by $\mathrm{pH}$ buffering with HOAc.

SYNFACTS Contributors: Philip Kocienski

Synfacts 2015, 11(1), 0003 Published online: 15.12.2014

Dol: 10.1055/s-0034-1379643; Reg-No.: K05714SF 